\title{
DETECTING AND RESPONDING TO BIOTERRORISM
}

\author{
Janet Martha Blatny \\ Forsvarets forskningsinstitutt (FFI), Norwegian Defence Research \\ Establishment, P.O. Box 25, N-2027 Kjeller, Norway
}

\section{Abstract}

Biological threat agents are infectious microorganisms such as bacteria, rickettsiae, fungi, viruses, or toxins with the intent to incapacitate or kill man, or to destroy livestock, crops, or food. The use of biological threat agents in biological warfare has a long history, but the recent use of anthrax spores in bioterrorism has urged the need for responding to such threats. The design of efficient and reliable detection and identification systems is a part of bioterrorism preparedness and response. Classical microbiology, immunoassays, and nucleic acid-based methods including molecular forensics are laboratory approaches for detecting and identifying various biological threat agents. These are supplementary methods needed for verification. However, the analysis results depend on the sample collection and handling. This chapter briefly summarizes some biological warfare and bioterrorism events, the threat posed by bioterrorism. Also, various methods and systems suitable for detection and identification of biological threat agents, with emphasis on environmental samples, are described.

\section{Introduction}

Biological warfare is the deliberate dispersion of infectious microorganisms (i.e., bacteria, rickettsiae, fungi, and viruses) or toxins with the intent to incapacitate or kill man, or to destroy livestock, crops or food. Toxins may be produced naturally by microorganisms, plants, or animals, or even synthesized chemically. Biological weapons (BWs) are weapons containing infectious biological material and are regarded as weapons of mass destruction (WMD), or more appropriately as weapons of mass casualty [reviewed in 1,2$]$. A BW is more than the biological agent alone and implies a delivery system such as a physical weapon (i.e., standard munitions, 
missiles, vehicle, and artillery shell). The Biological and Toxin Weapon Convention (BTWC) that entered into force in 1975 prohibits the development, production, and stockpiling of BWs. The use of such weapons is banned under the Geneva Protocol 1925. Still, it is strongly believed that some terrorist organizations and certain states, which are parties to the Convention, do possess BW programs. It is generally believed that biological threat agents are easily acquired and that their production is by "dual-use" equipment. For civilian purposes such equipment is used for production of beer, yoghurt, vaccines, and antibiotics. There are several barriers in obtaining an effective BW, and two of the major challenges are (i) the development of a sufficiently virulent and infectious strain for the seed stock and (ii) the selection of the most appropriate dissemination method of the biological threat agent.

The Centers for Disease Control and Prevention (CDC) has established a list of biological agents and toxins that may pose a severe threat to public health and safety (http://www.cdc.gov/od/sap). The requirements for including the agent or toxin to this "select agent list" are based on the effect on human health of exposure, the degree of contagiousness, the availability and effectiveness of medical treatment, and the vulnerability of various populations. Since October 2005, the reconstructed 1918 pandemic influenza virus has been added to this list. Table 1 provides examples of potential biological threat agents. The Australia Group has provided guidelines and control lists for national export of equipment, technology, and biological material that could contribute to BW activities (http://www.australiagroup.net/).

TABLE 1. Potential biological threat agents

\begin{tabular}{|c|c|c|c|c|}
\hline Microorganism & Disease & $\begin{array}{l}\text { Mortality } \\
\text { untreated }\end{array}$ & $\begin{array}{l}\text { Infective } \\
\text { dose }^{\mathrm{a}}\end{array}$ & $\begin{array}{l}\text { Incubation } \\
\text { time }^{d}\end{array}$ \\
\hline Bacillus anthracis & Anthrax & High & $\begin{array}{l}8,000-5,000 \\
\text { spores }\end{array}$ & $1-6 \mathrm{~d}$ \\
\hline Yersinia pestis & Plague $^{c}$ & High & $100-500 \mathrm{cfu}$ & $2-3 d$ \\
\hline $\begin{array}{l}\text { Francisella } \\
\text { tularensis }\end{array}$ & Tularemia & Low & $10-50 \mathrm{cfu}$ & $2-10 \mathrm{~d}$ \\
\hline Variola major & Smallpox $^{\mathrm{c}}$ & High & $10-100 \mathrm{pfu}$ & $7-17 \mathrm{~d}$ \\
\hline $\begin{array}{l}\text { Clostridium } \\
\text { botulinum }^{\mathrm{b}}\end{array}$ & Botulinum & High & $\begin{array}{l}0.003 \mu \mathrm{g} / \mathrm{kg} \\
\left(\mathrm{LD}_{50}\right)\end{array}$ & $1-5 \mathrm{~d}$ \\
\hline $\begin{array}{l}\text { Filovirus (e.g., } \\
\text { Ebola, Marburg) }\end{array}$ & $\begin{array}{l}\text { Viral } \\
\text { hemorrhagic } \\
\text { fevers }^{c}\end{array}$ & High & $1-10 \mathrm{pfu}$ & $4-21 \mathrm{~d}$ \\
\hline
\end{tabular}




\begin{tabular}{|c|c|c|c|c|}
\hline Coxiella burnetii & Q fever & Low & $30-3,000 \mathrm{cfu}$ & $10-40 \mathrm{~d}$ \\
\hline Brucella spp. & Brucellosis & Low & $10-100 \mathrm{cfu}$ & $5-60 d$ \\
\hline Vibrio cholerae & Cholera & Low & $10^{3}-10^{6} \mathrm{cfu}$ & $4 h-5 d$ \\
\hline Shigella spp. & Shigellosis ${ }^{c}$ & Low & $10-100 \mathrm{cfu}$ & $1-7 d$ \\
\hline Salmonella spp. & Salmonellosis & Low & $10-100 \mathrm{cfu}$ & $1-7 \mathrm{~d}$ \\
\hline $\begin{array}{l}\text { Escherichia coli } \\
\text { O157:H7 }\end{array}$ & STEC & Low & $<10^{3}$ & $10 \mathrm{~h}-3 \mathrm{~d}$ \\
\hline Ricin toxin & & High & $\begin{array}{l}3-5 \mu \mathrm{g} / \mathrm{kg} \\
\left(\mathrm{LD}_{50}\right)\end{array}$ & $18-24 \mathrm{~h}$ \\
\hline
\end{tabular}

${ }^{a}$ Infective dose as aerosol [3], except for food and water pathogens [4].

${ }^{\mathrm{b}}$ The toxin is the biological threat agent.

${ }^{c}$ Contagious human to human.

${ }^{\mathrm{d}} \mathrm{d}$, days; h, hours.

\section{Biological Warfare and Bioterrorism Events}

The use of biological agents in warfare has a long history [reviewed in 1]. During the Middle Age (14th century) the Tartars catapulted bodies of plague victims over the walls of Kaffa in an attempt to initiate an epidemic upon the residents. During the French and Indian Wars (17th century) blankets containing pus or dried scabs from patients infected with smallpox were given to the Native American tribes in order to transfer the disease. The Germans used biological agents for sabotage during the First World War such as infecting animal feed and horses intended for export. The Japan's biological warfare program during the Second World War included experiments using plague, cholera, and plague on prisoners, where more than 10,000 died (Unit 731). President Nixon terminated the US offensive BW programs in 1970 after signing the National Security Decisions 35 and 44. The BW program of the Sovjetunionen still continued (Biopreparat) after signing the BTWC in 1972. In 1979, anthrax spores were accidentally released from one of the BW research facilities in Sverdlovsk resulting in 66 deaths [5]. This unintentional release of anthrax spores demonstrated the effectiveness of infection by inhalation. In 1978, KGB assassinated the Bulgarian writer and journalist Markov by stabbing him with the tip of an umbrella containing a small pellet of ricin. The Rajneeshee Cult deliberately released Salmonella typhimurium at salad 
bars and supermarkets in Oregon, USA, in 1984, causing an outbreak of salmonellosis where 751 people fell ill [6]. The dissemination of anthrax spores by letters and the postal processing and distribution centers in the United States, in 2001, resulted in 22 cases of anthrax in which five of the inhalation cases were fatal [7]. A study performed by the Swedish Defence Research Agency [8] showed that the majority of incidents between 1960 and 1999 using biological material in order to kill, incapacitate, or threaten, included frequent use of ricin, HIV-infected blood, and food contaminants (e.g., Salmonella spp. and Shigella spp.).

\section{Bioterrorism Threat}

In order to assess a bioterrorism threat several factors need to be taken into account; the capability (technology and skills) and intention of the attackers, the vulnerability and the value of the action, and the harm of the biological agent [9]. There is a strong focus on the use of anthrax as a BW. This is due to the great stability of the anthrax spores ( $>80$ years), the effectiveness as an infectious agent by inhalation, and the easy dissemination of the spores. Many experts believe that biological threat agents may be more useful for obtaining panic and anxiety causing serious psychological impact instead of resulting in high numbers of casualties. The US senator Bill Frist stated at the World Economic Forum, Davos, January 2005 that "The greatest existential threat we have in the world today is biological" and that such an attack would occur at some time in the next 10 years. The Canadian Press reported in March 2005 that the military's intelligence arm has warned the federal government that avian flu may be a suitable biological threat agent. The 1918 pandemic influenza virus has recently been reconstructed by retrieving gene sequences from victims buried in the permafrost of Alaska and from preserved tissue samples $[10,11]$. The 1918 flu virus killed approximately 40 million people and might be regarded as one of the most effective bioweapon known. Newly emerging (e.g., SARS, Hendra, Nipah, and avian flu) and re-emerging (e.g., West Nile, human monkeypox, multidrug-resistant Mycobacterium tuberculosis) pathogenic microorganisms are of global concern urging the needs for national preparedness plans, and the development and production of vaccines, antivirals, and other therapeutics. These infectious agents could potentially be used in a deliberate biological attack. Three accidental escapes of the SARS virus from laboratories in Singapore and Beijing were reported in 2003 and 2004 [12]. Gene sequences may be purchased from various 
genes synthesis firms by e-mail requests. Few companies check and compare the ordered sequences against sequences from biological threat agents and there are no national regulations requiring these firms to do so. Thus, there is a concern that terrorists may order specific virulence genes and perform genetic engineering to create new or altered pathogenic microorganisms [13].

\section{Responding to Bioterrorism}

To minimize the effects of a biological attack, public health authorities need to be aware of the threat biological agents may have in biological warfare and bioterrorism.

Physicians need to be alerted and well-trained, have a high suspicion for these agents, and must recognize the clinical symptoms derived from such an infection. Symptoms of those exposed to such agents may be nonspecific and resemble common flu-like diseases. Many biological threat agents are zoonotic. Animals may show the first symptoms of a clinical infectious disease after a deliberate release of a biological agent. In such cases, veterinarians may be the first to encounter the disease caused by a zoonotic threat agent.

Planning for necessary actions, national and global coordination, responsibility, enhanced law enforcement, medical countermeasures, and implementing efficient syndromic surveillance systems are all essential parts of bioterrorism preparedness. In addition, designing efficient detection systems for early warning, and rapid and reliable diagnostic systems contributes to improve the response efforts. The avian flu outbreak in several Asian countries killing approximately 50 million chickens has revealed the need for establishing rapid molecular diagnostics for mass screening of the flu carriers to improve public health responses [14]. Early detection to a release of biological agents may decrease the infectious rate and the people exposed (Figure 1). By the time the clinical symptoms have emerged, it might be too late for treatment. In some cases, antibiotics may be effective as postexposure prophylaxis, but this treatment needs to start before the onset of symptoms.

\section{Biological Detection and Identification}

Biological threat agents may be difficult to detect and identify quickly and reliable both from a civilian (public health) and a military point of view. There is a distinction between the terms "detection" and "identification". The establishment of the presence or absence of a biological agent is termed 

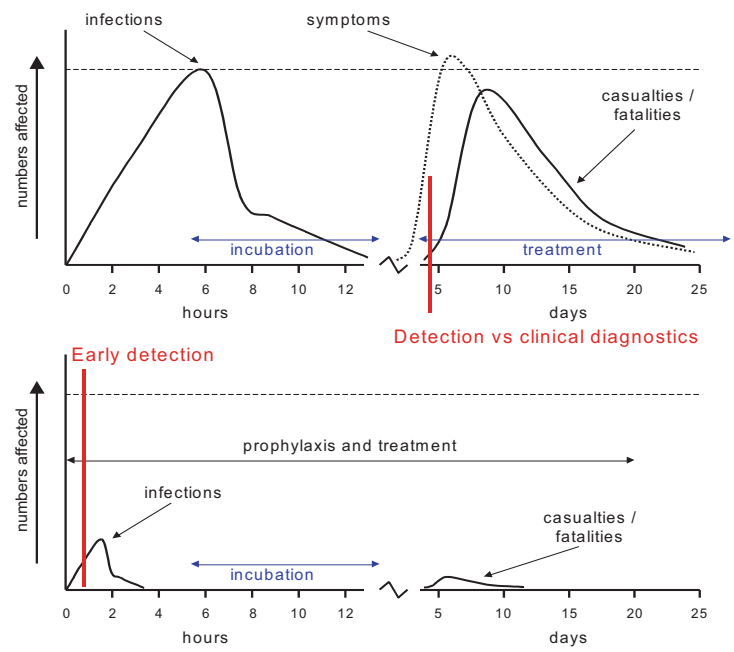

Figure 1. Early detection of a biological threat agent may reduce the number of infected individuals and casualties, and may be able to provide medical treatment before onset of symptoms.

detection, while identification is the determination of the precise nature of the biological agent. Many systems can only detect, and not identify the biological agent. The identification system is usually dependent on specific signatures (DNA, protein) of the microorganism. Identification of S. typhimurium as the causing strain for the deliberate outbreak of salmonellosis by the Rajneeshee Cult took 4 days, but it took more than a year to identify and confirm that only a single strain of $S$. typhimurium had been used (in addition to the confession by one of the cult members about the deliberate release). This illustrates that, in some cases, identification may be time-consuming. Many bacterial threat agents occur naturally, and some may be closely related to other bacteria found in the environment. Thus, it is necessary to distinguish between terrorist events, naturally occurring outbreaks, and background levels. False positives (i.e., alarm, but no agent) may arise when the biological detector device responds to detect and identify an interfering substance in the sample (contamination), which is not the actual biological agent. If a biological agent exists, but below an instrument's threshold value for detection and identification, a false negative may occur. Thus, the detection and identification schemes need to be carefully designed. 


\section{Detection Systems for Biological Threat Agents}

Efficient and reliable biodetection depends on the selectivity and sensitivity of the assay and system, as well as the collection and handling of the sample. A biological point detector for environmental (air) monitoring contains several components (Figure 2). A trigger may determine in real time any change in the biological background in air and discriminate between a biological threat agent and other particles in air, i.e., nonspecific detection. Particle sizers may be used as a trigger, exemplified by the Model 3321 Aerodynamic Particle Sizer from TSI and the Fluorescence Aerodynamic Particle Sizer FLAPS2 from Defence R\&D Canada. The FLAPS2 measures the intrinsic fluorescence produced by living microorganisms. Using an ultraviolet (UV) laser, the wavelength $266 \mathrm{~nm}$ excites fluorescence from the amino acids tryptophan and tyrosine, while $355 \mathrm{~nm}$ excites fluorescence from the cofactor NADH. A stand-off detector, such as light detection and ranging (LIDAR) may also be used as a trigger and for detecting potential biological threat clouds. LIDAR is regarded as a detect-to-warn system [15]. Short-range LIDARs can detect at a radius of approximately $5 \mathrm{~km}$ from the instrument. Most LIDARs use UV radiation at $266 \mathrm{~nm}$ or $355 \mathrm{~nm}$ such that biological material will fluoresce, but UV excitation may also fluoresce fuel oils, diesel, and agrochemicals causing false alarms. So far, LIDAR is not sufficiently operative during full daylight and needs good environmental conditions to function efficiently.

A collector is used for concentrating the biological particles in air usually into a liquid. Spores, bacteria, and viruses are usually together or attached to dust and other particles in air. Thus, the term "agent-containing particles per liter of air" (ACPLA) has been adopted. The first step in detecting ACPLA is to collect large enough air samples through a collector. The impinger SpinCon ${ }^{\circledR}$ air sampler from Sceptor Industries collects particles at a flow rate of $450 \mathrm{1} / \mathrm{min}$ in the range of $0.2-10 \mu \mathrm{m}$ into a liquid. OMNI 3000, based on the SpinCon ${ }^{\circledR}$ technology, and the Biotrace Intelligent Cyclone Air Sampler (ICAS) collects air with a flow rate of 300 and $750 \mathrm{~L} / \mathrm{min}$, respectively. The BioCapture 650 from MesoSystems is a portable handheld air collector, suitable for first responders, sampling at a flow rate of $200 \mathrm{~L} / \mathrm{min}$. The efficiency of air collection is also dependent on the size of the particles. FFI is using both the SpinCon ${ }^{\circledR}$ and OMNI 3000 air collector for outdoor and indoor sampling of air (Figure 3). These air samples are spiked with biological threat agents for polymerase chain reaction (PCR) analyses and determination of the detection limit (unpublished results). In many biodetection devices the trigger and detector have overlapping or the same functions. A detector is used to determine and characterize to a certain extent the biological origin of the aerosols. Even 


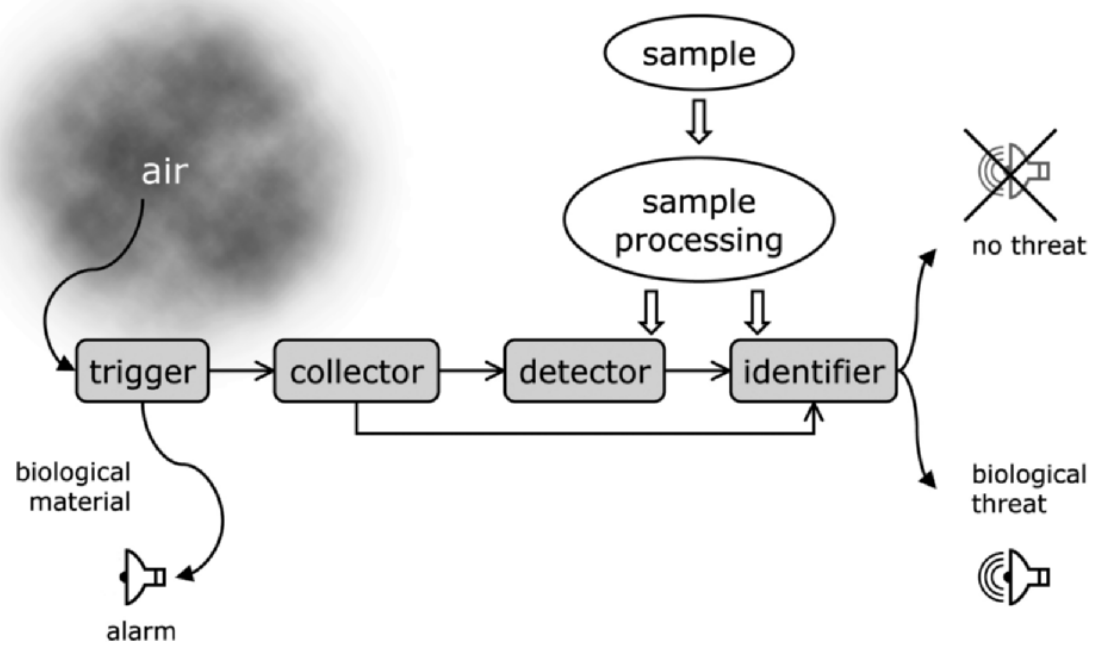

Figure 2. A biological point detection system for environmental monitoring (air) usually consists of a trigger, collector, detector, and identifier. Reliable and efficient detection and identification is dependent on the type of sample, sample collection, and sample processing.

though biological agents are detected, further identification of the agent is usually needed. An identifier performs specific identification of the biological threat agent (described in Section 5.1.8).

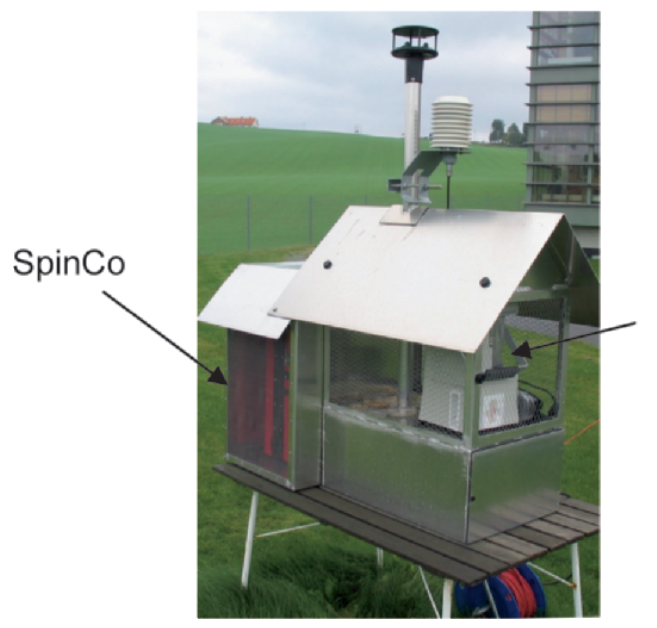

OMNI 3000

Figure 3. The SpinCon ${ }^{\circledR}$ and OMNI 3000 collector (Sceptor Industries) located outside FFI, Kjeller, for air sampling. 
Biological threat agents may be present as vegetative cells, spores, or in a dormant state (viable but nonculturable state; VBNC) in environmental samples (such as water, air, and soil). ATP is frequently used for nonspecific detection of viable bacterial cells (bioluminescence assays). Some of these assays have been further improved to separate bacterial ATP from nonbacterial ATP (yeast, somatic, or free ATP), and to detect spores. Spores are deficient in ATP and a germination step is required before performing the bioluminescence assay $[16,17]$. The bioluminescence assay combined with specific phage-associated lytic enzymes may be used for further identification of the bacteria.

\section{Identification of Biological Threat Agents}

There are several methods available for identifying biological threat agents, but there is no single approach for identification. Definitive identification requires several methods; conventional culture-based methods immunoassays, and nucleic acid-based methods (reviewed in [18-21]), as well as clinical diagnosis of those exposed to such agents. The cultivation of bacteria in selective growth medium allows detection of viable cells, inspection of colony morphology, and determination of antibiotic sensitivity. Such classical microbiology may identify the bacterial agent at the genus level and to a certain extent at the species level. However, these methods do not identify toxins, they are time-consuming, and not suitable for first responders.

\subsection{IMMUNOLOGICAL METHODS}

Immunoassays include the use of specific antibodies targeted against a toxin or a particular antigen at the surface of a bacterial cell or spore. Immunological methods usually provide quick results and are suitable for fast screening of a large number of samples. However, the method is less specific and sensitive, and the detection limit may be a 100-1,000-fold higher than the infective dose $[20,22]$. In general, immunoassays are good for presumptive detection but confirmatory analysis is needed, usually by nucleic acid-based detection methods. Antibody specificity and affinity are often the limiting factors of immunoassays. Tetracore's BioThreat Alert Test strips are reagent strips using a lateral flow immunochromatography technique allowing biological threat agents to be identified within $15 \mathrm{~min}$. Examples of commercially available immunological devices are the BioVeris detection system, Meso Scale Discovery Sector PR, and Luminex 100. 


\subsection{NUCLEIC ACID-BASED METHODS}

Real-time PCR is the most commonly used nucleic acid-based method for specific and sensitive identification of biological threat agents. PCR may detect as low as 10-100 cells, but this method usually requires a clean sample. Disruption of bacterial cells and spores is often needed in order to make the DNA available for amplification in the PCR assay. An effective sample preparation may also reduce the presence of false negatives since impurities from the sample may inhibit the PCR assay. Specific identification by PCR is obtained by using specific primers and probe combinations. Each probe (e.g., TaqMan probes, fluorescence resonance energy transfer [FRET]-prober, and molecular beacons) has a different method of separating the fluorophore from the quencher when reporting the amplification process. Different reporter dyes (fluorophores) may be attached to the probes allowing simultaneous identification of several biological threat agents (multiplex identification). The PCR assay should include internal controls to avoid false positive signals. Internal controls may consist of either a plasmid or a DNA fragment in which the amplified DNA sequence is unique in the assay $[23,24]$.

Several real-time PCR assays have been outlined for a number of biological threat agents, and commercial kits containing the specific reagents are available. The target genes and regions for PCR identification are specifically chosen for each microorganism. For Bacillus anthracis, several genetic targets located on the chromosome are used for identification [25-27] in addition to the well-known target lef, cya, pga toxin, and cap capsule genes located on the virulence $\mathrm{pXO} 1$ and $\mathrm{pXO} 2$ plasmids, respectively. However, plasmid-free $B$. anthracis cells will only be identified by PCR when using specific chromosomal targets. The closest relative of $B$. anthracis is the opportunistic human pathogen B. cereus (soil bacterium) and the insect pathogen $B$. thuringiensis. These are functionally different, mainly distinguish by plasmid-encoded genes. The genomes of $B$. anthracis, $B$. cereus, and B. thuringiensis strains show a close similarity [28] complicating the search for unique chromosomal targets for thier differentiation and identification. However, genome sequencing of many biological threat agents has provided significant data about unique regions that may be suitable as specific targets for PCR identification [29]. FFI has identified one unique chromosomal target for specific identification of $B$. anthracis (unpublished results). Several real-time PCR assays for identification of various biological threat agents listed in Table 1 have been established at FFI (exemplified in Figure 4) using either the SmartCycler from Cepheid and the LightCycler from Roche Applied 


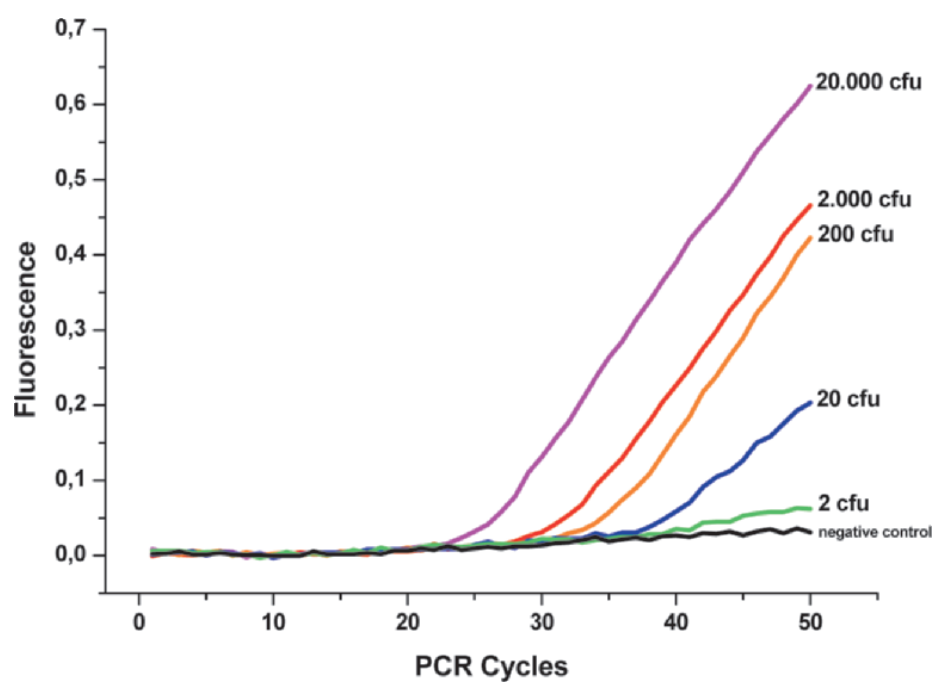

Figure 4. Identification of Coxiella burnetti (9 Mile, phase I) by PCR (Lightcycler ${ }^{\mathrm{TM}}$ ) using specific primers and probes (19).

Science (Figure 5). Idaho Technologies and Smiths detection (Bio-Seeq) have developed handheld PCR devices suitable for military use and first responders, such as Ruggedized advanced pathogen identification device (RAPID), and RAZOR, and Bio-Seeq, respectively. Bruker Daltonik GmbH has constructed a microarray system based on PCR for bioidentification. For review of various nucleic acid detection assays and systems see [18, 19, 21].

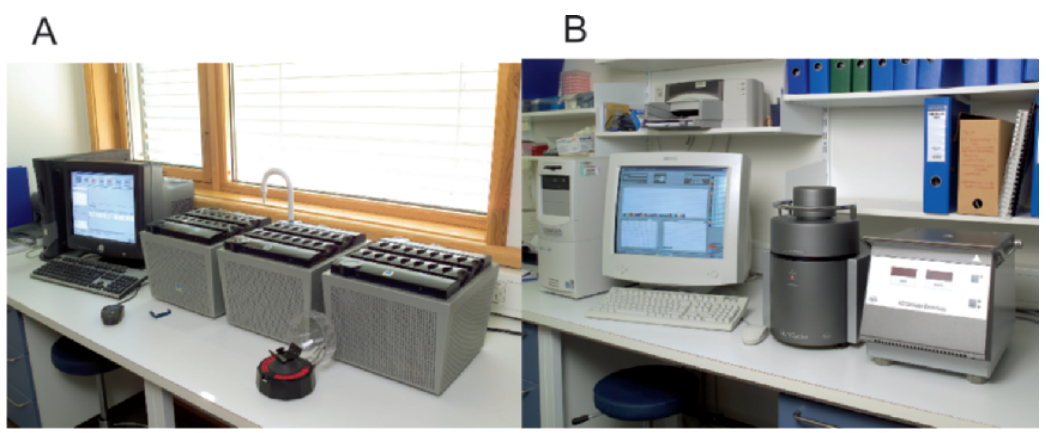

Figure 5. Real-time PCR devices at FFI. A, Smartcycler ${ }^{\mathrm{R}}$ (Cepheid); B, Lightcycler TM (Roche Applied Science). 
PCR can detect DNA from both viable and dead cells, and thus, culturebased methods are needed for the assessment of bacterial viability. Nucleic acid sequence-based amplification (NASBA) is a method in which RNA instead of DNA is amplified (reviewed in [30-32]). NASBA can be used to detect viable cells since mRNA is specifically detected and amplified. The design of specific primers and molecular beacons is crucial for the NASBA assay. NASBA has been widely used for virus diagnostics, and only few reports describe the use of this technique for bacterial detection. This technique has been used together with liposomal-based biosensors to identify $B$. anthracis, Escherichia coli, and Cryptosporidium parvum [33-35]. FFI has used NASBA for identification of Vibrio cholerae in water samples [36].

\section{Integrated and Advanced Detection Methods}

Biodetection equipment for use in a battlefield is different from the use in a civilian community. If deployed in the right place and at the right time, valuable information of a bioterrorism event would be provided. The Joint Biological Point Detection System (JBPDS) is an automatic point detector for real-time identification of biological threat agents within $15 \mathrm{~min}$ and suitable for military use. It contains a trigger, collector, detector, and identifier, and will be used by the US Air Force and Marine Corps. Integrated systems for identification of various biological threat agents in large areas (e.g., arenas, airports) and postal service systems have been constructed, such as the Autonomous Pathogen Detection System (APDS) from Lawrence Livermore National Laboratory and the BioHazard Detection System (BDS) from Northrop Grumman, respectively.

Other biodetection techniques in advance are light scattering surface plasmon resonance (LSSPR), surface-enhanced Raman spectroscopy (SERS), and matrix-assisted laser desorption/ionization time-of-flight mass spectroscopy (MALDI-TOF-MS). There have been many attempts to develop biosensors based on electrochemics, micro-fluidics, nanocrystals (quantum dots), and optics, combined with immuno- and nucleic acid-based assays, but only few are commercially available (reviewed in [37, 21]).

\section{Molecular Forensics}

Classification of bacterial strains is often based on the identification of DNA polymorphisms. When the genetic diversity within a bacterial species is high, it is often adequate to sequence only a few number of DNA 
fragments in order to classify the strain. In contrast, strains belonging to more homogenous species, in which little sequence divergence has occurred, it is necessary to sequence long DNA regions or to analyze several loci with high mutation rates. Variable number of tandem repeats (VNTR) is a linear arrangement of multiple copies of short repeated DNA sequences that vary in length and are highly polymorphic [38]. The size of the DNA fragments containing VNTRs is measured by PCR. Most bacterial genomes contain several VNTRs, and multi-locus VNTR (MLVA) analysis is now a suitable tool for strain typing and for tracing back to the origin of the bacterial agent [39]. VNTR analysis was used to identify the $B$. anthracis Ames strain used in the anthrax attacks in the United States in 2001 [40, 41, 29]. The United States has recently established a laboratory known as the National Bioforensics Analysis Center (NBFAC) operating together with the Federal Bureau of Investigation (FBI) [42]. The laboratory will handle an end-to-end analysis from sample collection to molecular typing. MLVA techniques have already been established at FFI and are used for genetic fingerprinting of $B$. cereus and $V$. cholerae strains (unpublished results).

\section{Conclusion}

Biological threat agents for the use in biological warfare or bioterrorism are infectious microorganisms or toxins with the intent to incapacitate or kill man, or to destroy livestock, crops, or food. An essential part of bioterrorism preparedness and response includes the design of efficient and reliable systems for detection and identification of biological threat agents. Various biodetection systems for environmental monitoring are available. Many of these systems have been primarily constructed for military use. There is no single approach for identification of biological threat agents, and several methods are needed for verification. Classical microbiology, immunoassays, and nucleic acid-based methods, including molecular forensics, are laboratory approaches for detecting, identifying, and verifying various biological threat agents.

\section{References}

1. Atlas RM. Bioterrorism: from threat to reality. Annu Rev Microbiol 2002; $56: 167-185$.

2. Davis RG. The ABCs of bioterrorism for veterinarians, focusing on Category A agents. Vet Med Today 2004; 224:1084-1095. 
3. Kortepeter M, Christopher G, Cieslak T, Culpepper R, Darling R, Pavlin J, Rowe J, McKee Jr. K, Eitzen Jr. E. USAMRIID'S Medical management of biological casualties handbook, Maryland, USA, 2001.

4. Granum PE. Smittsomme sykdommer fra mat. Høyskoleforlaget, 1999.

5. Meselson M, Guillemin J, Hugh-Jones M, Langmuir A, Popova V, Shelokov A, Yampolskaya V. The Sverdlovsk anthrax outbreak of 1979. Science 1994; 266:1202-1208.

6. Török T, Tauxe R, Wise R, Livengood J, Sokolow RA. Large community outbreak of salmonellosis caused by intentional contamination of restaurant salad bars. JAMA 1997; 278:389-395.

7. Jernigan DB, Raghunathan PL, Bell BP, Brechner R, Bresnitz EA, Butler JC, Cetron M, Cohen V, Doyle T, Fischer M, Greene C, Griffith KS, Guarner J, Hadler JL, Hayslett JA, Meyer R, Petersen LR, Phillips M, Pinner R, Popovic T, Quinn CP, Reefhuis J, Reissman D, Rosenstein N, Schuchat A, Shieh W, Siegal L, Swerdlow DL, Tenover FC, Traeger M, Ward JW, Weisfuse I, Wiersma S, Yeskey K, Zaki S, Ashford DA, Perkins BA, Ostroff S, Hughes J, Fleming D, Koplan JP, Gerberding JL, The National Anthrax Epidemiologic Investigation Team. Investigation of bioterrorism-related anthrax, United States, 2001: Epidemiologic findings. Emerg Inf Dis 2002; 8:1019-1028.

8. Melin L. Terrorism och kriminalitet. FOI report 1551-864 (in Swedish), 2000.

9. Ackerman GA, Moran KS. Bioterrorism and threat assessment. The weapons of mass destruction commission, No. 22, 2004.

10. Taubenberger JK, Reid AH, Lourens RM, Wang R, Jin G, Fanning TG. Characterization of the 1918 influenza virus polymerase genes. Nature 2005; 437:889-893.

11. Tumpey TM, Basler CF, Aguilar PV, Zeng H, Solorzano A, Swayne DE, Cox NJ, Katza JM, Taubenberger JK, Palese P, Garcia-Sastre A. Characterization of the reconstructed 1918 Spanish influenza pandemic virus. Science 2005; 310:77-80.

12. Von Bubnoff A. The 1918 flu virus is resurrected. Nature 2005; 437:794-795.

13. Aldhous P. The bioweapon is in the post. New Scientist 2005; 12:8-9.

14. Fung YW, Lau L, Yu AC. The necessity of molecular diagnostics for avian flu. Nat Biotechnol 2004; 22(3):267.

15. Baxter K, Clark JM. Set lasers to...detect. NBC International, Spring 2004, pp. 26-28.

16. Trudil D, Loomis L, Pabon R, Hasan JAK, Trudil CL. Rapid ATP method for the screening and identification of bacteria in food and water samples. Biocatalysis: Fundamentals and Applications 2000; 41:27-29.

17. Fujinami Y, Kataoka M, Matsushita K, Sekiguchi H, Itoi T, Tsuge K, Seto Y. Sensitive detection of bacteria and spores using a portable bioluminescence ATP measurement assay system distinguishing from white powder materials. J Health Sci 2004; 50:126-132.

18. Iqbal SS, Mayo MW, Bruno JG, Bronk BV, Batt CA, Chambers JP. A review of molecular recognition technologies for detection of biological threat agents. Biosens Bioelectron 2000; 15:549-578. 
19. Ivnitski D, O’Neil DJ, Gattuso A, Schlicht R, Calidonna M, Fisher R. Nucleic acid approaches for detection and identification of biological warfare and infectious disease agents. BioTechniques 2003; 35:862-869.

20. Peruski Jr. LF, Peruski AH. Rapid diagnostic assays in the genomic biology era: detection and identification of infectious disease and biological weapon agents. BioTechniques 2003a; 35:840-846.

21. Lim DV, Simpson JM, Kearns EA, Kramer MF. Current and developing technologies for monitoring agents of bioterrorism and biowarfare. Clin Microbiol Rev 2005; 18:583-607.

22. Peruski AH, Peruski Jr. LF. Immunological methods for detection and identification of infectious disease and biological warfare agents. Clin Diagn Lab Immun 2003b; 10:506-513.

23. Charrel RN, la Scola B, Raoult D. Multi-pathogens sequence containing plasmids as positive controls for universal detection of potential agents of bioterrorism. BMC Microbiol 2004; 4:1-11.

24. Inoue S, Noguchi A, Tanabayashi K, Yamada A. Preparation of a positive control DNA for molecular diagnosis of Bacillus anthracis. Jpn J Infect Dis 2004; 57:29-32.

25. Rastogi VK, Cheng T. Identification of anthrax-specific signature sequence from Bacillus anthracis. Proc. SPIE 2001; 4378:115-126. Chemical and Biological Sensing II (Gerdner, ed.).

26. Bavykin SG, Lysov YP, Zakhariev V, Kelly JJ, Jackman J, Stahl DA, Cherni, A. Use of $16 \mathrm{~S}$ rRNA, 23S rRNA, and $g y r B$ gene sequences analysis to determine phylogenetic relationships of Bacillus cereus group microorganisms. J Clin Microbiol 2004; 42:3711-3730.

27. Bode E, Hurtle W, Norwood D. Real-time PCR assay for a unique chromosomal sequence of Bacillus anthracis. J Clin Microbiol 2004; 42: 5826-5831.

28. Helgason E, Økstad OA, Caugant DA, Johansen HA, Fouet A, Mock M, Hegna I, Kolstø AB. Bacillus anthracis, Bacillus cereus, and Bacillus thuringiensis one species on the basis of genetic evidence. Appl Environ Microbiol 2000; 66:2627-2630.

29. Fraser CM. A genomics-based approach to biodefence preparedness. Nat Rev 2004; 5:23-33.

30. Chan AB, Fox JD. NASBA and other transcription-based amplification methods for research and diagnostic microbiology. Rev Med Microbiol 1999; 10:185-196.

31. Deiman B, van Aarle P, Sillekens P. Characteristics and applications of nucleic acid sequence-based amplification (NASBA). Mol Biotechnol 2002; 20:163-179.

32. Cook N. The use of NASBA for the detection of microbial pathogens in food and environmental samples. J Microbiol Methods 2003; 53:165-174.

33. Hartley HA, Baeumner AJ. Biosensor for the detection of a single viable B. anthracis spore. Anal Bioanal Chem 2003; 376:319-327. 
34. Baeumner AJ, Pretz J, Fang SA. universal nucleic acid sequence biosensor with nanomolar detection limits. Anal Chem 2004a; 76:888-894.

35. Baeumner AJ, Leonard B, McElwee J, Montagna RA. A rapid biosensor for viable $B$. anthracis spores. Anal Bioanal Chem 2004b; 380:15-23.

36. Fykse EM, Skogan G, Davies W, Olsen JS, Blatny JM. Detection of viable Vibrio cholerae cells by NASBA. Manuscript in preparation, 2005.

37. Deisingh AK, Thompson T. Biosensors for the detection of bacteria. Can J Microbiol 2004; 50:69-77.

38. Van Belkum A, Scherer S, van Alphen L, Verbrugh H. hort-sequence DNA repeats in prokaryotic genomes. Microbiol Mol Biol Rev 1998; 62:275-293.

39. Lindstedt BA. Multiple-locus variable number tandem repeats analysis for genetic fingerprinting of pathogenic bacteria. Electrophoresis 2005; 26:2567-2582.

40. Keim P, Price LB, Klevytska AM, Smith KL, Schupp JM, Okinaka R, Jackson PJ, Hugh-Jones ME. Multiple-locus variable-number tandem repeat analysis reveals genetic relationships within Bacillus anthracis. J Bacteriol 2000; 182:2928-2936.

41. Read TD, Peterson SN, Tourasse N, Baillie LW, Paulson IT, Nelson KE, Tettelin H, Fouts DE, Eisen JA, Gill SR, Holtzapple EK, Økstad OA, Helgason E, Rilstone J, Wu M, Kolonay JF, Beanan MJ, Dodson RJ, Brinkac LM, Gwinn M, DeBoy RT, Madpu R, Daugherty SC, Scott Durkin A, Haft DH, Nelson WC, Peterson JD, Pop M, Khouri HM, Radune D, Benton JL, Mahamoud Y, Jiang L, Hance IR, Weidman JF, Berry KJ, Plaut RD, Wolf AM, Watkins KL, Nierman WC, Hazen A, Cline R, Redmond C, Thwaite JE, White O, Salzberg SL, Thomason B, Friedlander AM, Koehler TM, Hanna PC, Kolstø $\mathrm{AB}$, Fraser CM. The genome sequence of Bacillus anthracis Ames and comparison to closely related bacteria. Science 2002; 296:2028-2033.

42. Budowle B, Schutzer SE, Ascher MS, Atlas RM, Burans JP, Chakraborty R, Dunn JJ, Fraser CM, Franz DR, Leighton TJ, Morse SA, Murch RS, Ravel J, Rock DL, Slezak TR, Velsko SP, Walsh AC, Walters RA. Toward a system of microbial forensics: from sample collection to interpretation of evidence. Appl Environ Microbiol 2005; 71:2209-2213. 